\title{
Comment \\ Comment on Aureli et al. Review of Historical Dam-Break Events and Laboratory Tests on Real Topography for the Validation of Numerical Models. Water 2021, 13, 1968
}

\author{
Eman AlQasimi and Tew-Fik Mahdi *(D) \\ Department of Civil, Geological and Mining Engineering, Polytechnique Montréal, University of Montréal \\ Campus, 2900 Boul. Édouard-Montpetit, Montreal, QC H3T 1J4, Canada; eman.alqasimi@polymtl.ca \\ * Correspondence: tewfik.mahdi@polymtl.ca; Tel.: +1-5143404711 (ext. 5874)
}

\begin{abstract}
This discussion points out that the available data of the Lake Ha! Ha! Dam failure, classified as useful for models' validation purposes by Aureli et al. (2021), present serious shortcomings that should move the Lake Ha! Ha! Dam from Aureli et al.'s well-documented test cases to cases with partial or inaccurate datasets.
\end{abstract}

Keywords: Lake Ha! Ha!; test cases; validation

\section{Introduction}

In [1], Aureli et al. presented a "review of the historical dam-break events for which

check for updates

Citation: AlQasimi, E.; Mahdi, T.-F. Comment on Aureli et al. Review of Historical Dam-Break Events and Laboratory Tests on Real Topography for the Validation of Numerical Models. Water 2021, 13, 1968. Water 2022, 14, 264. https://doi.org/ $10.3390 / w 14020264$

Academic Editor:

Karl-Erich Lindenschmidt

Received: 27 July 2021

Accepted: 17 December 2021

Published: 17 January 2022

Publisher's Note: MDPI stays neutral with regard to jurisdictional claims in published maps and institutional affiliations.

Copyright: (C) 2022 by the authors. Licensee MDPI, Basel, Switzerland. This article is an open access article distributed under the terms and conditions of the Creative Commons Attribution (CC BY) license (https:// creativecommons.org/licenses/by/ $4.0 /)$. real-field datasets useful for validation purposes can be retrieved in the literature" [1]. To this end "The resulting real-field test cases are divided into well-documented test cases, for which extensive and complete data are already available, and cases with partial or inaccurate datasets. Type and quality of the available data are specified for each case" [1]

In this discussion, the authors point out that the Lake Ha! Ha! Dam should not appear in the class of "well-documented historical dam-breaks found in the literature for which the writers have deemed the available data adequate to validate numerical models" [1]. In fact, Aureli et al. classified the well-documented dam-break test cases in Table 1 of their paper, and they included the Lake Ha! Ha! Dam in this category. A closer look to the data provided in [2] show that the data for the Lake Ha! Ha! Dam should not be used for the whole river reach.

\section{Available Data}

Of the cited references by Aureli et al. [1], Capart et al. [2] summarized most of the data related to the Ha! Ha! River. At 370 positions along the river from the Ha! Ha! Lake to the Saguenay River, they provided the cross-sections before and after the 1996 downpour. Moreover, a gradation curve valid for the first $10 \mathrm{~km}$ of the reach was published later [3].

\section{Previous Models}

Most of the researchers tried to capture the trend of the morphological changes. El Kadi and Paquier presented a 1D model claiming that it captured the changes "very well", even at the Perron Fall location [4]. At this location, most of the researchers have difficulties obtaining acceptable results. The "observed" available huge erosion, just upstream of Perron Falls, could not be modeled by AlQasimi and Mahdi [5], and after forcing data validation, they discovered the erroneous provided cross-sections just upstream of Perron Fall. More recently, for the same data set, Martínez-Aranda [6] blamed the limitations of their developed model on not capturing the "observed" morphological changes, instead of questioning the used available data of Capart et al. [2]. 


\section{Data Shortcomings}

Several authors have used the Capart et al. [2] data as mentioned by Aureli et al. [1]. Some of the provided cross-sections must be excluded from the data set. In fact, at the validation stage, it is easy to verify that some provided cross-sections are erroneous or incomplete [5]. Moreover, tworiver reaches require special consideration when using the available data. The lake's dam did not fail, but a secondary dike, the Cut-Away dike, did, and the water flow created a new 2.5-kilometer path through a forest. In this zone, trees were removed, and huge erosion occurred due to the flowing waterpower. This is a debris flow that cannot be simulated using the Saint-Venant equations. Nevertheless, all the used models were simulated this case as if the water flowed over an area without trees. The provided cross-sections in this area were given assuming no trees. The second zone needing special attention is located $22 \mathrm{~km}$ downstream of the Cut-Away dike, just upstream of Perron Falls, where, as noted in [5], "a new river path was created during the 1996 flood. The available initial cross-sections are along the old riverbed, and the available post-flood cross-sections are along the new river path. Hence, in this zone, the pre-flood cross-sections provided in [2] are not the right ones to use for the simulations. Once this river zone is excluded, only the upper reach, $8.4 \mathrm{~km}$ long, can be modeled". In fact, one needs a hydraulics control as a downstream boundary condition for simulating the flood. The only available control, a waterfall, is located $8.4 \mathrm{~km}$ from the Cut-Away dike. Hence, only the first $8.4 \mathrm{~km}$ can be used for models based on the Saint-Venant equations, assuming no debris flow in the first $2.5 \mathrm{~km}$ at the beginning of the failure flood.

\section{Conclusions}

Aureli et al. [1] are to be commended for their "review of the historical dam-break events for which real-field datasets useful for validation purposes can be retrieved in the literature" as this is the first paper summarizing these events. However, the original paper included the Lake Ha! Ha! Dam in this category. This should not be the case because the existing data have the following shortcomings:

- $\quad$ Some of the cross-sections are erroneous. Even if visualization of the cross-sections allows the identification of the erroneous ones, uncertainty persists regarding the validity of the remaining ones;

- Debris flow occurred during the failure flood. The failure of a secondary dike created a new path for the water in an existing forest leading to huge erosion and removal of trees;

- During the flood, $22 \mathrm{~km}$ downstream the secondary dike, just upstream of Perron Falls, a new river path was created, rending the use of the available cross-sections useless for any validation case study.

- $\quad$ The only existing hydraulics control upstream of Perron Falls is located $8.4 \mathrm{~km}$ away from the failed dike.

The only possible use of the Lake Ha! Ha! Dam data is limited to the first $8.4 \mathrm{~km}$ of the $37 \mathrm{~km}$ of provided cross-sections. Moreover, an additional assumption, negligible debris flow duration, is needed to use a model based on the Saint-Venant equation. The Lake Ha! Ha! Dam case should be classified under Aureli et al.'s cases with partial or inaccurate datasets and not in their well-documented test cases.

Author Contributions: The study was designed by T.-F.M. The findings are based on the original work of E.A. and T.-F.M. analyzed the original article and wrote the paper, and E.A. reviewed it. All authors have read and agreed to the published version of the manuscript.

Funding: This research was funded, in part, by National Science and Engineering Research Council (NSERC) Discovery Grant for the corresponding author, application No: RGPIN-2021-03272.

Conflicts of Interest: The authors declare no conflict of interest. The founding sponsors had no role in the design of the study; in the collection, analyses, or interpretation of data; in the writing of the manuscript, and in the decision to publish the results. 


\section{References}

1. Aureli, F.; Maranzoni, A.; Petaccia, G. Review of Historical Dam-Break Events and Laboratory Tests on Real Topography for the Validation of Numerical Models. Water 2021, 13, 1968. [CrossRef]

2. Capart, H.; Spinewine, B.; Young, D.L.; Zech, Y.; Brooks, G.R.; Leclerc, M.; Secretan, Y. The 1996 Lake Ha! Ha! Breakout Flood, Québec: Test Data for Geomorphic Flood Routing Methods. J. Hydraul. Res. 2007, 45, 97-109. [CrossRef]

3. Mahdi, T.-F.; Marche, C. Prévision par modélisation numérique de la zone de risque bordant un tronçon de rivière subissant une crue exceptionnelle. Can. J. Civ. Eng. 2003, 30, 568-579. [CrossRef]

4. El Kadi Abderrezzak, K.; Paquier, A. One-dimensional numerical modeling of sediment transport and bed deformation in open channels. Water Resour. Res. 2009, 45, W05404. Available online: https://agupubs.onlinelibrary.wiley.com/action/ showCitFormats?doi=10.1029\%2F2008WR007134 (accessed on 17 November 2021). [CrossRef]

5. AlQasimi, E.; Mahdi, T.-F. Flooding of the Saguenay Region in 1996: Part 1—Modeling River Ha! Ha! Flooding. Nat. Hazards 2019, 96, 1-15. [CrossRef]

6. Martínez-Aranda, S.; Murillo, J.; García-Navarro, P. A 1D numerical model for the simulation of unsteady and highly erosive flows in rivers. Comput. Fluids 2019, 181, 8-34. [CrossRef] 